\title{
Multimedia Interactive Learning in Science Subjects for Grade Fourth Elementary School Students
}

\author{
Mega Putri Islamyati ${ }^{1 *}$ Ida Bagus Surya Manuaba ${ }^{2}$ iD \\ ${ }^{1}$ Pendidikan Guru Sekolah Dasar, Universitas Pendidikan Ganesha, Singaraja, Indonesia \\ *Corresponding author: megaputriislamyati27@undiksha@ac.id
}

\begin{abstract}
Abstrak
Bahan ajar dan hasil belajar daring yang kurang maksimal mempengaruhi proses pembelajaran. Siswa memerlukan visualisasi yang dapat membantu mengkonkretkan pemahaman materi, khususnya dalam pelaksanaan pembelajaran daring. Tujuan penelitian ini untuk mengembangkan multimedia pembelajaran interaktif pada mata pelajaran IPA menurut validasi uji ahli dan uji coba perorangan. Penelitian pengembangan ini menerapkan model DDD-E (Decide, Design, Develop, Evaluate). Metode yang digunakan untuk mengumpulkan data adalah angket yang dilengkapi dengan observasi dan wawancara. Analisis data yang digunakan adalah analisis deskriptif kuantitatif dan kualitatif. Subjek penelitian pengembangan ini berupa multimedia pembelajaran interaktif kemudian dilakukan review dari validator ahli isi mata pelajaran, ahli desain instruksional, ahli media pembelajaran, dan uji coba perorangan pada siswa. Hasil analisis data berdasarkan validasi oleh ahli isi materi pelajaran diperoleh persentase skor sebesar 96,15\% dengan kualifikasi sangat baik, ahli desain instruksional diperoleh persentase skor sebesar 87,5\% dengan kualifikasi baik, ahli media pembelajaran diperoleh persentase skor sebesar 93,00\% dengan kualifikasi sangat baik, dan hasil review 3 orang siswa dalam uji coba perorangan diperoleh persentase skor sebesar 91,66\% dengan kualifikasi sangat baik. Berdasarkan hasil yang diperoleh, maka dapat disimpulkan bahwa multimedia pembelajaran interaktif yang dikembangkan sangat layak untuk digunakan dalam pembelajaran IPA siswa kelas VI SD.
\end{abstract}

Kata kunci: Multimedia Pembelajaran, Interaktif, IPA

\section{Abstract}

Teaching materials and online learning outcomes that are less than optimal affect the learning process. Students need visualization that can help concrete understanding of the material, especially in implementing online learning. This study aimed to develop interactive multimedia learning in science subjects according to the validation of expert tests and individual trials. This development research applies the DDD-E model (Decide, Design, Develop, Evaluate). The method used to collect data is a questionnaire equipped with observations and interviews. The data analysis used is quantitative and qualitative descriptive analysis. The subject of this development research is interactive learning multimedia. Then a review is carried out from subject content expert validators, instructional design experts, learning media experts, and individual trials on students. The results of data analysis based on validation by subject matter content experts obtained a percentage score of $96.15 \%$ with very good qualifications, instructional design experts obtained a score percentage of $87.5 \%$ with good qualifications, learning media experts obtained a percentage score of $93.00 \%$ with very good qualifications, and the results of the review of 3 students in individual trials obtained a percentage score of $91.66 \%$ with very good qualifications. Based on the results obtained, it can be concluded that the interactive learning multimedia developed is very feasible in science learning for sixth-grade elementary school students.

Keywords: Learning Multimedia, Interactive, natural Science

\begin{tabular}{|c|c|c|}
\hline History: & & Publisher: Undiksha Press \\
\hline Received & : March 19, 2021 & Licensed: This work is licensed under \\
\hline Revised & : March 21, 2021 & a Creative Commons Attribution 3.0 License \\
\hline Accepted & : April 10, 2021 & (c) (i) (?) \\
\hline Published & : April 25, 2021 & (cc) ${ }_{B Y}$ SA $_{S A}$ \\
\hline
\end{tabular}

\section{Introduction}

At this time, the whole world is facing a viral pandemic that brings many changes to occur. The World Health Organization has defined Corona Virus Disease (Covid-19) as a pandemic that has affected more than 200 countries globally (Mehrsafar et al., 2021; Sohrabi et al., 2020). The United Nations stated that one of the sectors greatly affected by this epidemic was the world of education (Lim et al., 2021; Wijaya et al., 2020). Several countries 
have temporarily decided to close educational institutions to prevent the spread of Covid-19 through social distancing (Hincal \& Alsaadi, 2021; Shah et al., 2020).

One of the actions taken by the Ministry of Education and Culture Directorate of Education through Circular No. 4 of 2020 directs learning from home (BDR) activities. As a result, the learning process is carried out with a system in an online network (online) through media such as Google Classroom, Zoom, and WhatsApp (Durnali, 2020; Hong et al., 2021; Yulia, 2020). Online learning is a form of presenting conventional learning born in digital format via the internet utilizing currently developing technology (Imania \& Bariah, 2019; Rhim \& Han, 2020). Through this phenomenon, everyone is forced to be technology literate as a bridge that can connect teachers and students in learning without face to face during certain conditions such as the implementation of online learning (Tang et al., 2021; Wijaya et al., 2020).

The facts found at the observation site, namely at SD Negeri 3 Sesetan, South Denpasar, in the implementation of online learning, it is known that the acquisition of the Middle Semester Science Assessment for grade VI students is still low. Through interviews, it was stated that most online learning students had difficulties understanding the material independently. One of the reasons is the limitations of the learning media used, which are only textbooks from schools and learning videos from Youtube, which are not by the learning objectives. The teacher's role in facilitating the student learning process by applying various learning strategies and variations in learning media is one factor that affects student learning outcomes (Abror et al., 2020; Febliza \& Okatariani, 2020).

In addition to evaluating the student's learning process, the actual student learning outcomes can be seen as an evaluation of teacher teaching (El-Magboub et al., 2016; Sholihin et al., 2020). Students will find it challenging to understand the material without selecting the proper concept application in the learning process. In this situation, the teacher is tasked with overcoming these limitations through an essential learning component to achieve learning objectives in the presence of learning media (Abror et al., 2020; Febliza \& Okatariani, 2020; Riyanto \& Gunarhadi, 2017). learning can increase new desires and interests, generate motivation, stimulate learning activities, and bring psychological effects on students (Ristanti \& Arianto, 2019; Seruni et al., 2020).

Science learning should be packaged according to the nature of science as a product, process, and scientific attitude (Lo et al., 2021). Science learning emphasizes providing a direct experience that aims to develop competencies to explore and understand the natural surroundings (Anif et al., 2020; Setiawan et al., 2017). P The use and learning of science are related to how to find out about nature systematically so that science is not only mastery of a collection of knowledge in the form of facts, concepts, or principles but also a process of discovery and formation of scientific attitudes (Maison et al., 2020; Subali et al., 2019).

Elementary school students need special treatment because their cognitive abilities still have limitations to understanding abstract concepts or knowledge in learning (Hwang et al., 2013; Puspitarini \& Hanif, 2019). The learning process should be adjusted to the characteristics of students to make it easier to understand concepts or material ideas based on facts from the learning experience carried out (Anif et al., 2020; Wijanarko, 2017). Based on the explanation of the statement, the problem is how to make science material well-received, maximally, and produce a positive active response from students.

Based on these problems, it is considered necessary to develop learning media. Previous research related to the use of learning media shows that the multimedia developed can be used publicly (Komalasari \& Rahmat, 2019; Riyanto \& Gunarhadi, 2017). Other research shows that the developed learning multimedia effectively improve students' science learning outcomes (Nur Jannah, 2020; Rubini et al., 2018). Other research shows that interactive learning multimedia is effectively used to improve science learning outcomes so 
that it is suitable for use in the learning process (Permana \& Nourmavita, 2017; Saifudin et al., 2020). Based on the research and development that has been done, the use of technology in learning is considered to be able to attract students' interest in learning.

One of them is through Interactive Learning Multimedia, which combines material in the form of textual, audio, and visual as a learning tool and a means of communication (Bdiwi et al., 2019; Lai et al., 2019). Learning in the form of visualization as outlined by technology is considered to help students understand situations, concepts, and ideas of abstract material, especially in science learning content (Chandra et al., 2020; Rizaldi et al., 2020). Besides being expected to increase conceptual knowledge, the media is made interactive, which means there is an interaction between two or more directions of the elements provided in the media (Sargeant, 2015; Uygarer \& Uzunboylu, 2017). Pictures, audio, quizzes, summaries, and flexible navigations are combined using software, one of which is Articulate Storyline. Articulate Storyline is software that can be used as a presentation or communication.

This developed media has differences and advantages from previously developed media. Media with the final form in HTML5 can be easily shared and accessed via smartphones, laptops, or computers. The availability of interactive science learning multimedia can provide direct experience, for example, to analyze the types of plant adaptations through materials or see video shows directly in multimedia with various sound explanations and animation effects that are by KD and indicators in the 2013 Curriculum syllabus. Students in understanding and learning the subject matter quickly and fun. In addition to the content already mentioned, a feature is also provided to measure student activity and learning outcomes in operating the developed product, namely in the form of question evaluations that can provide confirmation pop-ups or feedback regarding the explanation of answers so that students know which answers are correct and which are not. This product is also equipped with navigation buttons that allow students to operate freely and select the menu or page they want to learn, thus enabling students to study independently according to their abilities and interests. Based on the explanation of the problems above, this research aims to develop interactive multimedia learning in science subjects.

\section{Methods}

This research is a type of development research using the DDD-E model. The DDD-E model consists of Decide (setting the objectives of the program material), Design (making the program structure), Develop (developing or producing media elements and creating media displays), and Evaluate (evaluating or checking the entire design and development process) (Tegeh \& Kirna, 2010). The research development product that will be produced is interactive multimedia learning on science learning in the material adaptation of plants to their environment for sixth-grade elementary school students to improve students' understanding. In this development research, only the quality test of subject content experts, learning design experts, learning media experts, and individual trials.

Data collection methods used in this study were observation, interviews, and questionnaires/questionnaires. This development research was conducted when observing the school environment, conditions, and student learning activities. Interviews in this study were conducted with the homeroom teacher of grade VI elementary school and a grade VI elementary school student to get in-depth information related to the problems that exist in the learning process. The questionnaire method was used when analyzing student characteristics, evaluating reviews from subject content experts, learning design experts, learning media experts, and product trials on students' trials.

The experts consist of 1 subject matter expert, one expert in instructional/learning design and learning media. While the individual trial on grade VI students at SD Negeri 3 
Sesetan. The questionnaire given using a closed questionnaire consists of 13 statements in the subject matter expert questionnaire consisting of 4 aspects, namely learning aspects, material aspects, language aspects, and evaluation aspects. The following is a grid of questionnaires for subject content experts, instructional/learning design experts, learning media experts, and student responses.

Table 1. Subject Content Expert Questionnaire Grid

\begin{tabular}{|c|c|c|}
\hline No & Aspect & Indicator \\
\hline \multirow[t]{3}{*}{1} & Learning & The suitability of the material with basic competencies \\
\hline & & The suitability of the material with the learning indicators \\
\hline & & The suitability of the material with the learning objectives \\
\hline \multirow[t]{6}{*}{2} & Material & Material truth \\
\hline & & Clarity of material description \\
\hline & & Clarity of the examples provided \\
\hline & & The importance of the material \\
\hline & & The suitability of the material with the characteristics of students \\
\hline & & Easy to understand material \\
\hline \multirow[t]{2}{*}{3} & Language & $\begin{array}{l}\text { The accuracy of the use of terms in accordance with the rules of the } \\
\text { Indonesian language }\end{array}$ \\
\hline & & Suitability of language with the level of development of students \\
\hline \multirow[t]{2}{*}{4} & Evaluation & The suitability of the evaluation with the material \\
\hline & & $\begin{array}{l}\text { The suitability of the level of difficulty of the question with } \\
\text { competence }\end{array}$ \\
\hline
\end{tabular}

Table 2. Learning Design Expert Questionnaire

\begin{tabular}{|c|c|c|}
\hline No & Aspect & Indicator \\
\hline \multirow[t]{2}{*}{1} & Visual Display & Exciting multimedia performance \\
\hline & & $\begin{array}{l}\text { Clarity of components (text, images, audio, animation) in } \\
\text { multimedia }\end{array}$ \\
\hline 2 & Learning & $\begin{array}{l}\text { Clarity and consistency of basic competencies, indicators, learning } \\
\text { objectives, materials, and evaluation }\end{array}$ \\
\hline \multirow[t]{2}{*}{3} & Material & Suitability of material order \\
\hline & & $\begin{array}{l}\text { The suitability of the material with the learning objectives } \\
\text { Interesting material description }\end{array}$ \\
\hline \multirow[t]{3}{*}{4} & Effects in & Helps remember previous abilities and knowledge \\
\hline & Learning & Media support for students' independence and motivation to learn \\
\hline & Strategies & $\begin{array}{l}\text { The ability of the media to increase students' knowledge and } \\
\text { understanding }\end{array}$ \\
\hline 5 & Evaluation & $\begin{array}{l}\text { Conformity of evaluation with competency achievement indicators } \\
\text { Instructions for working on questions are given }\end{array}$ \\
\hline
\end{tabular}

Table 3. Learning Media Expert Questionnaire Grid

\begin{tabular}{lll}
\hline No & Aspect & Indicator \\
\hline 1 & Technical & Media according to KD \\
& & Media according to Indicator \\
& & Ease of using media \\
\hline
\end{tabular}




\begin{tabular}{lll}
\hline No & Aspect & Indicator \\
\hline \multirow{3}{*}{ Visual Display } & Media can help students in understanding the material \\
& Media can generate student motivation in learning \\
& Theme consistency \\
& The use of images supports learning materials \\
& Use the right typeface, font size and spacing \\
& Composition and color combinations that are right and match \\
& Proper use of animation \\
& Appropriate accompaniment music support \\
& Clarity of concepts in the media \\
& Use of appropriate narrative \\
& Text legibility \\
& Screen display is harmonious and balanced \\
\hline
\end{tabular}

The data analysis method used in this development research is descriptive quantitative analysis method and qualitative descriptive analysis. The qualitative descriptive method is used to process data from reviewers so that they can be grouped so that input and suggestions from experts can be used as a reference to improve the product being developed. The quantitative descriptive analysis method is used to process data that is still in the form of scores to become the percentage of responses from the subjects studied. Quantitative descriptive analysis is used to process the data obtained through a questionnaire in the form of a score using a Likert Scale.

\section{Results and Discussion Results}

The first stage, namely Decide, is carried out by setting instructional goals, determining the theme or scope of the material, determining the prerequisite knowledge or abilities, and assessing the availability of smartphones and other required resources such as computers, laptops, and stable internet connections. The activity of setting instructional goals is carried out before determining the multimedia theme of interactive learning. This activity is carried out to emphasize interactive learning multimedia products towards the required learning. Another purpose of the activity of setting learning objectives is to consider the development carried out in order to achieve the specified goals.

Based on the results of interviews conducted with teachers to analyze teacher needs and student characteristics in learning, it is known that there are difficulties for teachers in creating a learning media that can be accessed by students independently at home and easy to understand the online learning process. The limited learning media that only uses textbooks from schools and YouTube learning videos are not by the learning objectives to be achieved. Based on the previous considerations, then the determination of KD and temporal indicators is carried out.

Plant Adaptation with Basic Competencies 3.3 Analyzing how living things adapt to the environment with Indicators categorizing plant characteristics related to their habitat, comparing plant physical characteristics, identifying the benefits of parts related to their habitat, analyzing how plants adapt to the environment, and analyzing how plants protect from his enemy. Through a needs questionnaire survey conducted to find out the needs of students, it is known that students are thrilled to learn using engaging media that includes videos and sample images that concretize the material. In the prerequisite skills, it is known that most students can operate smartphones, laptops, and computers. At the resource assessment stage, it is known that most of the sixth graders already have personal smartphones that can support the operation of this interactive learning multimedia. 
The second stage, namely Design, is obtained and produces several essential things, including outline content, flowcharts, initial appearance design, storyboards, compiling media assessment instruments, and preparing lesson plans (RPP). In making the content outline, it is taken into account that the products made make it easier for students to understand the material and in the operation of the media to be facilitated according to the abilities of elementary school students then packaged in an attractive form of interactive learning multimedia that contains videos, images, animations, and audio in it. Making flowcharts or flowcharts is necessary for making interactive learning multimedia to facilitate the visualization of a program's images, sequences, and structures. Then proceed with designing the initial appearance in a sketch or initial framework of the product to be developed. This stage is deemed necessary to facilitate the actual manufacturing process.

Making a storyboard contains a visual description of interactive learning multimedia on a smartphone, computer, or laptop screen. The created storyboard contains the information displayed on the screen and other supporting information to develop interactive learning multimedia components in the preparation of this instrument in the form of a questionnaire used to determine the feasibility and quality of the products that have been developed. Questionnaires were created and intended for experts, and students included: (1) subject content experts, (2) instructional design experts, (3) learning media experts, and (4) individual trials. The preparation of lesson plans aims to direct students' learning activities using interactive multimedia learning, which was developed based on the 2013 Curriculum and adapted to the characteristics and constraints experienced by students in learning. All design stages have been adjusted and developed based on the problems found in the field.

The third stage, namely Develop or develop, includes combining elements such as text, animation, visuals, and audio that are used and then integrated and published (publish) into interactive learning multimedia applications, making questionnaires, product validation by material experts, validation of instructional designs, and validation-learning media expert. The interactive learning multimedia display design is made using the Articulate Storyline 3 application. An articulate Storyline is software that can be used to create interactive learning multimedia; this software is commonly used as a communication tool and presentation media. Animated images, videos, and other elements used are downloaded via the internet with the listed sources. The design made is adapted to the material loaded, namely the way plants adapt (adaptation) to their environment so that the design is made with a green hill background with several plants. The multimedia display design developed is presented in Figure 1.

After the application has been produced, the next stage is product validation by experts and product testing. Product trials are conducted to determine the feasibility of the product to be used in the learning process. The last stage is Evaluate (evaluation), a formative evaluation carried out during the development process to perfect the product being developed. The results obtained from the test subjects are used as a benchmark for improving or perfecting the developed product. The review was conducted by subject matter experts, instructional/learning design experts, learning media experts, and students through individual trials. This trial activity aims to find out the validity of the developed product. 


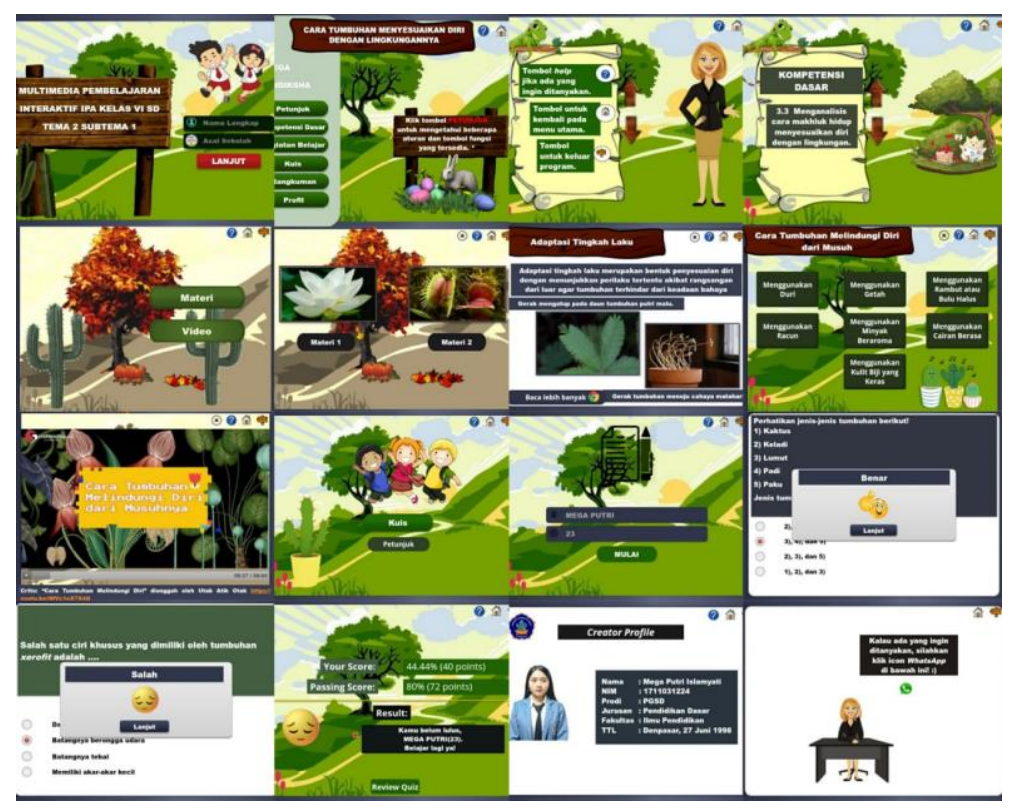

Figure 1. Design of Interactive Learning Multimedia Display

The results of interactive learning multimedia products assessed by content experts for science subjects got the achievement percentage of $96.15 \%$ with very good qualifications. Assessment of interactive learning multimedia products carried out by learning design experts, got the results of the achievement percentage of $87.5 \%$ with good qualifications. The learning media assessment of interactive learning multimedia products obtained a 93\% achievement percentage with very good qualifications. Individual trials get $91.66 \%$ achievement percentage results with very good qualifications.

Based on the results above, it can be concluded that interactive learning multimedia can be declared feasible to be used in the learning process with a few revisions. The input provided by subject content experts, learning design experts, and learning media experts is considered to perfect interactive multimedia learning development. As for input and suggestions from experts, namely, complete practice questions with answer keys, provide clear instructions for working on questions and provide sources/copyrights on videos or images downloaded via the internet. Furthermore, the developed multimedia has been revised according to the input given by the experts.

\section{Discussion}

Based on the results of quality tests that have been carried out, the development of interactive learning multimedia shows excellent qualifications from the assessment of experts and individual trials. The developed interactive learning multimedia is declared suitable for use in the learning process. This is also because the interactive learning multimedia development process uses an appropriate and systematic development model to minimize errors in the product development process (Riwu et al., 2018; Sukmana \& Suartama, 2019). The development of this interactive learning multimedia uses the DDD-E model, which goes through several stages, namely the stages of deciding, designing, developing, and evaluating or evaluating at each stage so that the development carried out becomes more structured.

Excellent qualifications on each indicator can be achieved due to several aspects, namely. First, the material contained in the product has been developed based on Basic Competencies, Indicators, and learning objectives according to the 2013 Curriculum syllabus (Hest et al., 2021; Uygarer \& Uzunboylu, 2017). Second, the material presented in the 
product is clear and coherent and strengthened by the provision of examples such as images, videos, and animations that are appropriate to the learning material (Wahyuni \& Yokhebed, 2019; Weng et al., 2018). Third, the use of sentences and language in the product is straightforward and by the language development of students (Churchill et al., 2013; Lai et al., 2019). Fourth, the level of difficulty of the questions and the suitability of the evaluation questions with the learning objectives are appropriate. Learning objectives are the main component that must be formulated in learning because they are the targets of the learning process (Kalyuga, 2012; Sajnani \& Mayor, 2020).

Clarity and linkage between learning media and indicators, objectives, and materials must be a concern and consideration for teachers to choose and use media in the learning process in the classroom so that the media used are more effective and efficient to achieve learning objectives (J Rizki et al., 2008; Kartika et al., 2019). Based on these statements, it can be concluded that the clarity and relevance of indicators, essential competencies, learning objectives, material presentation, language use, and the suitability of evaluation with learning objectives contained in interactive learning multimedia will facilitate teachers and students in learning. So that it will have an impact on student learning outcomes, thus learning objectives will be maximally achieved (Garbin et al., 2020; Komalasari \& Rahmat, 2019).

In the results of the design expert's assessment, six indicators scored with excellent qualifications, and the other six indicators scored with suitable qualifications. This is due to several aspects, namely: (1) the formulation of the indicators contained in the multimedia is by the learning indicators, (2) the learning materials contained in the multimedia are explicit, (3) the methods, learning steps, assessment techniques, and instruments the assessment used in applying multimedia in learning is appropriate, and (4) accuracy in media selection to facilitate learning. Learning design is an essential overall process in analyzing learning needs, goals and developing delivery systems to achieve learning quality (Admadja et al., 2016; Riyanto \& Gunarhadi, 2017).Based on these statements, it can be concluded that learning designs that are by the characteristics of learning and students will be more effective in facilitating students in learning so that it will positively impact student learning outcomes. Thus learning objectives will be maximally (Abdulrahaman et al., 2020; Majid et al., 2012).

Media that combines many elements, one of which is interactivity, can make the learning process more exciting and effective because it involves more than one sense in learning so that it can stimulate students in learning and will have a positive impact on student learning outcomes (Marnita \& Ernawati, 2017; Rubini et al., 2018). The learning objectives are to be achieved optimally. The findings of previous research also stated that interactive multimedia learning could motivate creativity in learning passion skills, clarify and facilitate message presentation, overcome the limitations of time, space, and sensory power for both students and teachers (Heo \& Toomey, 2020; Manurung \& Panggabean, 2020). In addition, interactive multimedia learning can develop students' ability to interact directly with the environment and learning resources, enabling students to learn independently according to their abilities and interests (Bus et al., 2020; Lee \& Osman, 2012). Based on these statements, it can be concluded that the interactive learning multimedia developed has been packaged clearly and attractively according to the characteristics of students and can be operated easily so that it can be used as an alternative learning resource. This research implies that teachers in learning can apply the developed interactive learning multimedia.

\section{Conclusion}

The Interactive Learning Multimedia product that was developed got excellent qualifications based on the assessments of experts and students. So it can be concluded that 
the Multimedia Interactive Learning Material Elements of Intrinsic Fairy tales is very feasible to learn Indonesian in Class III Elementary School in the online and offline learning process.

\section{References}

Abdulrahaman, M. D., Faruk, N., Oloyede, A. A., Surajudeen-bakinde, N. T., \& Olawoyin, L. A. (2020). Multimedia tools in the teaching and learning processes: A systematic review. Heliyon, 6(October), e05312. https://doi.org/10.1016/j.heliyon.2020.e05312

Abror, M., Suryani, N., \& Ardianto, D. T. (2020). Digital Flipbook Empowerment as A Development Means for History Learning Media. JPI (Jurnal Pendidikan Indonesia), 8(2), 266. https://doi.org/10.23887/jpi-undiksha.v8i2.24122

Admadja, Perwira, I., \& Marpanji., E. (2016). Pengembangan Multimedia Pembelajaran Praktik Individu Instrumen Pokok Dasar Siswa SMK di Bidang Keahlian Karawitan. Jurnal Pendidikan Vokasi, 6(2). https://doi.org/10.21831/jpv.v6i2.8107

Anif, S., Sutopo, A., \& Prayitno, H. J. (2020). Lesson study validation: Model for social and natural sciences teacher development in the implementation of national curriculum in Muhammadiyah schools, Indonesia. Universal Journal of Educational Research, 8(1), 253-259. https://doi.org/10.13189/ujer.2020.080132

Bdiwi, R., de Runz, C., Faiz, S., \& Cherif, A. A. (2019). Smart learning environment: Teacher's role in assessing classroom attention. Research in Learning Technology, 27, 1-14. https://doi.org/10.25304/rlt.v27.2072

Bus, A. G., Neuman, S. B., \& Roskos, K. (2020). Screens, Apps, and Digital Books for Young Children: The Promise of Multimedia. AERA Open, 6(1), 233285842090149. https://doi.org/10.1177/2332858420901494

Chandra, A. Y., Kurniawan, D., \& Musa, R. (2020). Perancangan Chatbot Menggunakan Dialogflow Natural Language Processing (Studi Kasus: Sistem Pemesanan pada Coffee Shop). Jurnal Media Informatika Budidarma, 4(1), 208. https://doi.org/10.30865/mib.v4i1.1505

Churchill, D., King, M., \& Fox, B. (2013). Learning design for science education in the 21st century. Zbornik Instituta Za Pedagoska Istrazivanja, 45(2), 404-421. https://doi.org/10.2298/ZIPI1302404C

Durnali, M. (2020). The effect of self-directed learning on the relationship between selfleadership and online learning among university students in Turkey. Tuning Journal for Higher Education, 8(1), 129-165. https://doi.org/10.18543/tjhe-8(1)-2020pp129-165 Received

El-Magboub, A., Haworth, I. S., Sutch, B. T., \& Romero, R. M. (2016). Evaluation of inclass and online discussion meetings in a biopharmaceutics problem-based learning class. Currents in Pharmacy Teaching and Learning, 8(6), 811-820. https://doi.org/10.1016/j.cptl.2016.08.021

Febliza, A., \& Okatariani, O. (2020). The Development of Online Learning Media by Using Moodle for General Chemistry Subject. Journal of Educational Science and Technology (EST), 6(1), 40. https://doi.org/10.26858/est.v6i1.12339

Garbin, C., Zhu, X., \& Marques, O. (2020). Dropout vs. batch normalization: an empirical study of their impact to deep learning. Multimedia Tools and Applications, 79(19-20), 2777-12815. https://doi.org/10.1007/s11042-019-08453-9

Heo, M., \& Toomey, N. (2020). Learning with multimedia: The effects of gender, type of multimedia learning resources, and spatial ability. Computers and Education, 146, 103747. https://doi.org/10.1016/j.compedu.2019.103747

Hest, Y. A. L., Riyadi, Kamsiyati, S., \& Purnamasari, V. (2021). Pengembangan Bahan Ajar Berbasis Muatan Lokal Keanekaragaman Motif Batik Ngawi sebagai Sumber Belajar di Kelas V Sekolah Dasar. Jurnal Basicedu, 5(2), 1060-1066. 
https://doi.org/10.31004/basicedu.v5i1.721

Hincal, E., \& Alsaadi, S. H. (2021). Stability analysis of fractional order model on corona transmission dynamics. Chaos, Solitons \& Fractals, 143, 110628. https://doi.org/10.1016/j.chaos.2020.110628

Hong, J.-C., Lee, Y.-F., \& Ye, J.-H. (2021). Procrastination predicts online self-regulated learning and online learning ineffectiveness during the coronavirus lockdown. $\begin{array}{lllll}\text { Personality and Individual Differences, } & 170673 .\end{array}$ https://doi.org/10.1016/j.paid.2021.110673

Hwang, G. J., Yang, L. H., \& Wang, S. Y. (2013). A concept map-embedded educational computer game for improving students' learning performance in natural science courses. Computers \& Education, 69. https://doi.org/10.1016/j.compedu.2013.07.008

Imania, K. A., \& Bariah, S. K. (2019). Rancangan Pengembangan Instrumen Penilaian Pembelajaran Berbasis Daring. Jurnal Petik, 5(1), 31-47. https://doi.org/10.31980/jpetik.v5i1.445

J Rizki, R., Setiawan, W., \& R Fitajaya, E. (2008). Optimalisasi Macromedia Flash Untuk Mendukung Pembelajaran Berbasis Komputer Pada Program Studi Ilmu Komputer FPMIPA UPI. Jurnal Pendidikan Teknologi Informasi Dan Komunikasi, 1(2), 1-10. https://doi.org/10.31219/osf.io/8jf6v

Kalyuga, S. (2012). Interactive distance education: A cognitive load perspective. Journal of Computing in Higher Education. https://doi.org/10.1007/s12528-012-9060-4

Kartika, Y., Wahyuni, R., Sinaga, B., \& Rajagukguk, J. (2019). Improving Math Creative Thinking Ability by using Math Adventure Educational Game as an Interactive Media. Journal of Physics: Conference Series, 1179(1), 1-6. https://doi.org/10.1088/17426596/1179/1/012078

Komalasari, K., \& Rahmat, R. (2019). Living Values Based Interactive Multimedia in Civic Education Learning. International Journal of Instruction, 12(1), 113-126. https://doi.org/10.29333/iji.2019.1218a

Lai, A. F., Chen, C. H., \& Lee, G. Y. (2019). An augmented reality-based learning approach to enhancing students' science reading performances from the perspective of the cognitive load theory. British Journal of Educational Technology, 50(1), 232-247. https://doi.org/10.1111/bjet.12716

Lee, T. T., \& Osman, K. (2012). Interactive Multimedia Module in the Learning of Electrochemistry: Effects on Students' Understanding and Motivation. Procedia - Social and Behavioral Sciences, 46. https://doi.org/10.1016/j.sbspro.2012.05.295

Lim, M. T. C., Ramamurthy, M. B., Aishworiya, R., Rajgor, D. D., Tran, A. P., Hiriyur, P., Kunaseelan, S., Jabri, M., \& Goh, D. Y. T. (2021). School closure during the coronavirus disease 2019 (COVID-19) pandemic - Impact on children's sleep. Sleep Medicine, 78(January 2020), 108-114. https://doi.org/10.1016/j.sleep.2020.12.025

Lo, J.-H., Lai, Y.-F., \& Hsu, T.-L. (2021). The Study of AR-Based Learning for Natural Science Inquiry Activities in Taiwan's Elementary School from the Perspective of Sustainable Development. Sustainability, 13(3). https://doi.org/10.3390/su13116283

Maison, M., Haryanto, H., Ernawati, M. D. W., Ningsih, Y., Jannah, N., Puspitasari, T. O., \& Putra, D. S. (2020). Comparison of student attitudes towards natural sciences. International Journal of Evaluation and Research in Education, 9(1), 54-61. https://doi.org/10.11591/ijere.v9i1.20394

Majid, M. S. Z. B. A., Ali, M. M. B. A., Rahim, A. A. B. A., \& Khamis, N. Y. B. (2012). The Development of Technical English Multimedia Interactive Module to Enhance Student Centered Learning (SCL). Procedia - Social and Behavioral Sciences, 67, 345-348. https://doi.org/10.1016/j.sbspro.2012.11.337

Manurung, \& Panggabean. (2020). Improving Students' Thinking Ability In Physics Using 
Interactive Multimedia Based Problem Solving. Cakrawala Pendidikan, 39(2), 460-470. https://doi.org/10.21831/cp.v39i2.28205

Marnita, \& Ernawati. (2017). The Use of Interactive Multimedia (Macromedia Flash) to Increase Creative Thinking Ability of Students in Basic Physics Subject. Jurnal Pendidikan Fisika Indonesia, 13(2), 71-78. https://doi.org/10.15294/jpfi.v13i2.10152

Mehrsafar, A. H., Moghadam Zadeh, A., Jaenes Sánchez, J. C., \& Gazerani, P. (2021). Competitive anxiety or Coronavirus anxiety? The psychophysiological responses of professional football players after returning to competition during the COVID-19 $\begin{array}{llll}\text { pandemic. } & \text { Psychoneuroendocrinology, } & \text { 129(January), } & 105269 .\end{array}$ https://doi.org/10.1016/j.psyneuen.2021.105269

Nur Jannah, I. (2020). Efektivitas Penggunaan Multimedia dalam Pembelajaran IPA di SD. Jurnal Ilmiah Sekolah Dasar, 4(1), 54. https://doi.org/10.23887/jisd.v4i1.24135

Permana, E. P., \& Nourmavita, D. (2017). Pengembangan Multimedia Interaktif Pada Mata Pelajaran Ipa Materi Mendeskripsikan Daur Hidup Hewan Di Lingkungan Sekitar Siswa Kelas Iv Sekolah Dasar. Jurnal PGSD, 10(2), 79-85. https://doi.org/10.33369/pgsd.10.2.79-85

Puspitarini, Y. D., \& Hanif, M. (2019). Using Learning Media to Increase Learning Motivation in Elementary School. Anatolian Journal of Education, 4(2), 53-60. https://doi.org/10.29333/aje.2019.426a

Rhim, H. C., \& Han, H. (2020). Teaching online: foundational concepts of online learning and practical guidelines. Korean Journal of Medical Education, 32(3), 175-183. https://doi.org/10.3946/kjme.2020.171

Ristanti, F. F., \& Arianto, F. (2019). Flash Card Media Utilization To Improve Student Activity and Learning Outcomes of Fauna Distribution Subtopic in Class Xi Ips I Sma Xin Zhong Surabaya. Geosfera Indonesia, 4(2), 90. https://doi.org/10.19184/geosi.v4i2.9968

Riwu, I. U., Laksana, D. N. L., \& Dhiu, K. D. (2018). Pengembangan Bahan Ajar Elektronik Bermuatan Multimedia Pada Tema Peduli Terhadap Makhluk Hidup Untuk Siswa Sekolah Dasar Kelas Iv Di Kabupaten Ngada. Journal of Education Technology, 2(2), 56. https://doi.org/10.23887/jet.v2i2.16182

Riyanto, W. D., \& Gunarhadi, G. (2017). The Effectiveness of Interactive Multimedia in Mathematic Learning: Utilizing Power Points for Students with Learning Disability. IJPTE: International Journal of Pedagogy and Teacher Education, 1(1), 55-63. https://doi.org/10.20961/ijpte.v1i1.8400

Rizaldi, D. R., Nurhayati, E., \& Fatimah, Z. (2020). The Correlation of Digital Literation and STEM Integration to Improve Indonesian Students' Skills in 21 st Century. International Journal of Asian Education, 1(2), 73-80. https://doi.org/10.46966/ijae.v1i2.36

Rubini, B., Permanasari, A., \& Yuningsih, W. (2018). Learning Multimedia Based on Science Literacy on the Lightning Theme. Jurnal Penelitian Dan Pembelajaran IPA, 4(2), 89-104. https://doi.org/10.30870/jppi.v4i2.3926

Saifudin, M., Susilaningsih, S., \& Wedi, A. (2020). Pengembangan Multimedia Interaktif Materi Sumber Energi untuk Memudahkan Belajar Siswa SD. JKTP: Jurnal Kajian Teknologi Pendidikan, 3(1), 68-77. https://doi.org/10.17977/um038v3i12019p068

Sajnani, N., \& Mayor, C. et al. (2020). Aesthetic presence: The role of the arts in the education of creative arts therapists in the classroom and online. Arts in Psychotherapy, 69(February), 101668. https://doi.org/10.1016/j.aip.2020.101668

Sargeant, B. (2015). What is an ebook? What is a Book App? And Why Should We Care? An Analysis of Contemporary Digital Picture Books. Children's Literature in Education, 46(4), 454-466. https://doi.org/10.1007/s10583-015-9243-5

Seruni, R., Munawaroh, S., Kurniadewi, F., \& Nurjayadi, M. (2020). Implementation of e- 
module flip PDF professional to improve students' critical thinking skills through problem based learning. Journal of Physics: Conference Series, 1521(4), 1-6. https://doi.org/10.1088/1742-6596/1521/4/042085

Setiawan, Innatesari, D. K., Sabtiawan, W. B., \& Sudarmin, S. (2017). The development of local wisdom-based natural science module to improve science literation of students. Jurnal Pendidikan IPA Indonesia, 6(1), 49-54. https://doi.org/10.15294/jpii.v6i1.9595

Shah, K., Arfan, M., Mahariq, I., Ahmadian, A., Salahshour, S., \& Ferrara, M. (2020). Fractal-Fractional Mathematical Model Addressing the Situation of Corona Virus in Pakistan. Results in Physics, 19, 103560. https://doi.org/10.1016/j.rinp.2020.103560

Sholihin, M., Sari, R. C., Yuniarti, N., \& Ilyana, S. (2020). A new way of teaching business ethics: The evaluation of virtual reality-based learning media. The International Journal of Management Education, 18(3). https://doi.org/10.1016/j.ijme.2020.100428

Sohrabi, C., Alsafi, Z., O’Neill, N., Khan, M., Kerwan, A., Al-Jabir, A., Iosifidis, C., \& Agha, R. (2020). World Health Organization declares global emergency: A review of the 2019 novel coronavirus (COVID-19). International Journal of Surgery, 76(February), 71-76. https://doi.org/10.1016/j.ijsu.2020.02.034

Subali, B., Kumaidi, Aminah, N. S., \& Sumintono, B. (2019). Student achievement based on the use of scientific method in the natural science subject in elementary school. Jurnal Pendidikan IPA Indonesia, 8(1), 39-51. https://doi.org/10.15294/jpii.v8i1.16010

Sukmana, A. I. W. I. Y., \& Suartama, I. K. (2019). Pengembangan Mobile Learning Berorientasi Model Pembelajaran Flipped Classroom Pada Mata Kuliah Multimedia. Journal of Education Technology, 2(1), 45. https://doi.org/10.23887/jet.v2i1.13808

Tang, Y. M., Chen, P. C., Law, K. M. Y., Wu, C. H., Lau, Y., Guan, J., He, D., \& Ho, G. T. S. (2021). Comparative analysis of Student's live online learning readiness during the coronavirus (COVID-19) pandemic in the higher education sector. Computers \& Education, 168, 104211. https://doi.org/10.1016/j.compedu.2021.104211

Tegeh, I. M., \& Kirna, I. M. (2010). Metodeogi Penelitian Pengembangan Pendidikan. Universitas Pendidikan Ganesha.

Uygarer, R., \& Uzunboylu, H. (2017). An investigation of the digital teaching book compared to traditional books in distance education of teacher education programs. Eurasia Journal of Mathematics, Science and Technology Education, 13(8), 5365-5377. https://doi.org/10.12973/eurasia.2017.00830a

Wahyuni, E. S., \& Yokhebed. (2019). Deskripsi Media Pembelajaran Yang Digunakan Guru Biologi Sma Negeri Di Kota Pontianak. Jurnal Pendidikan Informatika Dan Sains, 8(1), 32. https://doi.org/10.31571/saintek.v8i1.1105

Weng, C., Otanga, S., Weng, A., \& Cox, J. (2018). Effects of interactivity in E-textbooks on 7th graders science learning and cognitive load. Computers \& Education, 120, 172-184. https://doi.org/10.1016/j.compedu.2018.02.008

Wijanarko, Y. (2017). Model Pembelajaran Make a Match Untuk Pembelajaran IPA Yang Menyenangkan. Taman Cendekia: Jurnal Pendidikan Ke-SD-An, 1(1), 52. https://doi.org/10.30738/tc.v1i1.1579

Wijaya, T. T., Ying, Z., Purnama, A., \& Hermita, N. (2020). Indonesian students' learning attitude towards online learning during the coronavirus pandemic. Psychology, Evaluation, and Technology in Educational Research, 3(1). https://doi.org/10.33292/petier.v3i1.56

Yulia. (2020). Online Learning to Prevent the Spread of Pandemic Corona Virus in Indonesia. ETERNAL (English Teaching Journal), 11(1). https://doi.org/10.26877/eternal.v11i1.6068 